Research Article

\title{
Size Selectivity of Anionic and Cationic Dyes Using LDH Modified Adsorbent with Low-Cost Rambutan Peel to Hydrochar
}

\author{
N. Normah ${ }^{1}$, Novie Juleanti ${ }^{1}$, Patimah Mega Syah Bahar Nur Siregar ${ }^{1,4}$, Alfan Wijaya ${ }^{4}$, \\ Neza Rahayu Palapa ${ }^{3}$, Tarmizi Taher ${ }^{2,4}$, Aldes Lesbani ${ }^{3,4, *}$ \\ ${ }^{1}$ Magister Programme Graduate School of Mathematics and Natural Sciences, Sriwijaya University, \\ Jl. Padang Selasa No. 524 Ilir Barat 1, Palembang, South Sumatra, Indonesia. \\ ${ }^{2}$ Departement of Environmental Engineering, Faculty of Mathematics and Natural Sciences, Insitut Teknologi \\ Sumatera, Jl. Terusan Ryacudu, Way Hui, Jati Agung, Lampung 35365, Indonesia. \\ ${ }^{3}$ Graduate School of Faculty Mathematics and Natural Sciences, Sriwijaya University, Jl. Padang Selasa No. 524 \\ Ilir Barat 1, Palembang, South Sumatra, Indonesia. \\ ${ }^{4}$ Research Center of Inorganic Materials and Coordination Complexes, Faculty of Mathematics and Natural \\ Sciences, Universitas Sriwijaya, Jl. Palembang Prabumulih Km.32 Ogan Ilir 30662, Indonesia.
}

Received: $20^{\text {th }}$ August 2021; Revised: $14^{\text {th }}$ September 2021; Accepted: $14^{\text {th }}$ September 2021 Available online: $20^{\text {th }}$ September 2021; Published regularly: December 2021

\section{Abstract}

Modification of the layered double hydroxide of $\mathrm{CuAl}-\mathrm{LDH}$ sy composite with hydrochar (HC) to form $\mathrm{CuAl}-\mathrm{HC}$ LDH. Material characterization by XRD, FT-IR and SEM analysis was used to prove the success of the modification. The characterization of XRD and FT-IR spectra showed similarities to pure LDH and HC. Selectivity experiments were carried out by mixing malachite green, methylene blue, rhodamine-B, methyl orange, and methyl red to produce the most suitable methyl blue dye for $\mathrm{CuAl}-\mathrm{LDH}, \mathrm{HC}$ and $\mathrm{CuAl}-\mathrm{HC}$ adsorbents. The effectiveness of $\mathrm{CuAl}-\mathrm{HC} \mathrm{LDH}$ as adsorbent on methylene blue adsorption was tested through several influences such as adsorption isotherm, thermodynamics, and adsorbent regeneration. CuAl-HC LDH adsorption isotherm data shows that the adsorption process tends to follow the Langmuir isotherm model with a maximum adsorption capacity of $175.439 \mathrm{mg} / \mathrm{g}$ with a threefold increase compared to pure LDH. The effectiveness of the adsorbent for repeated use reaches five cycles as evidenced by the maximum capacity regeneration data reaching $82.2 \%, 79.3 \%, 77.9 \%, 76.1 \%$, and $75.8 \%$.

Copyright (C 2021 by Authors, Published by BCREC Group. This is an open access article under the CC BY-SA License (https://creativecommons.org/licenses/by-sa/4.0).

Keywords: CuAl-LDHs; Hydrochar; Composite; Selectivity; Regeneration

How to Cite: N. Normah, N. Juleanti, P.M.S.B.N. Siregar, A. Wijaya, N.R. Palapa, T. Taher, A. Lesbani (2021). Size Selectivity of Anionic and Cationic Dyes Using LDH Modified Adsorbent with Low-Cost Rambutan Peel to Hydrochar. Bulletin of Chemical Reaction Engineering \& Catalysis, 16(4), 869-880 (doi:

10.9767/bcrec.16.4.12093.869-880)

Permalink/DOI: https://doi.org/10.9767/bcrec.16.4.12093.869-880

\section{Introduction}

Industrial development is increasing to meet market needs and the needs of the mass population, so industrial waste is also increasing which

\footnotetext{
* Corresponding Author.

Email: aldeslesbani@pps.unsri.ac.id (A. Lesbani)
}

can cause environmental pollution [1,2]. Based on many studies, researchers report that it is estimated that more than $7 \times 10^{5}$ tons of substances approximately $12-14 \%$ of the color produced annually become industrial waste after the manufacturing process and disposal in the environment $[1,3,4]$. Industrial sources that use 
a lot of dyes usually come from several industries such as paper, plastics, cosmetics, photography, food, ink, refining, pharmaceutical and textile industries [5-8]. In general, dyes are classified as cationic dyes and anionic dyes [1]. Methylene blue (MB) with the chemical formula $\mathrm{C}_{16} \mathrm{H}_{18} \mathrm{ClN}_{3} \mathrm{~S}$ is one of the most abundant cationic dyes and is most commonly applied in industrial, biological, and chemical dyes [4,5,9]. Dyes usually have a stable aromatic complex structure so that the warning substance will be more difficult to decompose/degrade in nature [7]. However, its disposal directly into the environment will have a negative effect on both aquatic life and humans. This is because dyes are mutagenic, carcinogenic, and toxic/poisonous [2]. Water contamination by various organics discharged from industry into the environment has recently become dyes [10]. Thus, this issue should be addressed to remove and decontaminate dyes from wastewater to ensure a safe environment using efficient water treatment technologies $[8,9]$.

Currently, many researchers report that there are several methods that have been developed to remove pollutants in wastewater. In general, various methods, physics and biology are used in wastewater treatment, such as electrochemistry, oxidation, biodegradation, chemical chemistry, coagulation, photocatalysis, membrane filtration, flocculation, ion exchange, ozonation, filtration, and adsorption $[4,6,11,12]$. Among these methods, adsorption is the most appropriate method and has many advantages for removing methylene blue from wastewater. This adsorption method has many advantages such as having high efficiency, easy to carry out, cost-effective alternative, simple method, easy to operate, produces unwanted by-products, and availability of large amount of adsorbent [13-16]. On the other hand, the important factor that has the greatest influence on the adsorption efficiency is represented by the adsorbent [17]. The effectiveness of the adsorbent in the adsorption process is one of the factors to obtain high adsorption capacity, large selectivity, thermal and chemical, and easy preparation [17,18]. Many adsorbents have been applied to remove methylene blue from solution, such as kaolin, activated carbon, cellulose, coal fly ash, bentonite, biomass, chitosan, as well as layered double hydroxide $[3,7,16,19-$ 21].

Recently developed materials have been developed. One of them is a layered material whose synthesis is layered double hydroxide $(\mathrm{LDH})$ which has an adjustable usage density and great chemical uniformity [18]. LDH is an anionic clay with a positively charged layer $[22,23]$. This structure greatly contributes to its anionic exchange capacity. LDH or materials such as hydrotalcite have a chemical composition expressed by the formula $\left[\mathrm{M}^{2+} 1-\mathrm{xM}^{3+} \mathrm{x}\right.$ $\left.(\mathrm{OH})_{2}\right]^{\mathrm{x}^{+}}\left[\mathrm{A}^{\mathrm{n}-} \mathrm{x} / \mathrm{n} \cdot \mathrm{mH}_{2} \mathrm{O}\right]$ with metal substitution $\mathrm{M}^{3+}$ for $\mathrm{M}^{2+}$, and an anion-containing interlayer and molecular solvation, where $\mathrm{M}^{2+}$ is like; $\mathrm{Mg}^{2+}, \mathrm{Zn}^{2+}$, or $\mathrm{Ni}^{2+}$, and $\mathrm{M}^{3+}$, such as; $\mathrm{Al}^{3+}, \mathrm{Ga}^{3+}$, $\mathrm{Fe}^{3+}$, or $\mathrm{Mn}^{3+}$. The $\mathrm{An}^{\mathrm{n}-}$ is the anion present in the layer, i.e. $\mathrm{CO}_{3}, \mathrm{Cl}^{-}, \mathrm{SO}_{4}, \mathrm{RCO}_{2}$, while $x$ are typically between 0.2 and 0.4 [13,24-26]. $\mathrm{LDH}$ has been widely used as a dye adsorbent because it has a high adsorption capacity and has a large surface area [14].

On the other hand, repeated use of LDH is ineffective because the structure of $\mathrm{LDH}$ will be exfoliated [27]. Therefore, it is necessary to improve the structure of LDH by modifying LDH. One of them, LDH modification can be done by forming a composite that combines two materials [28]. One of the materials that can be composited with LDH is a carbon-based material. Based on research by Lesbani et al. [14], $\mathrm{NiAl} \mathrm{LDH}$ composited with biochar and used to adsorb methylene blue (MB). Biochar from rice husk was used as a matrix for the formation of NiAl LDH/Biochar composites. This adsorbent has an adsorption capacity of $61.72 \mathrm{mg} / \mathrm{g}$, while pure $\mathrm{LDH}$ only reaches $22.98 \mathrm{mg} / \mathrm{g}$. In a recent study conducted by Kundu \& Naskar, (2021) [15] modification of LDH with carbon into carbon-LDH nanocomposite was applied to remove inorganic contaminants (metals of $\mathrm{As}(\mathrm{V})$, $\mathrm{Fe}(\mathrm{II}) / \mathrm{Fe}(\mathrm{III}), \mathrm{F}^{-}$) and organic (methylene blue and methyl orange) in aqueous solution.

This study modified CuAl-LDH by forming a composite with hydrochar from rambutan peel (Nephelium lappaceum L.) which was applied as an adsorbent to remove methylene blue. This study used the coprecipitation method for the synthesis of CuAl-LDH. CuAl-LDH is made of divalent and trivalent metals, namely divalent $\mathrm{Cu}^{2+}$ metal cations and trivalent $\mathrm{Al}^{3+}$ metal cations. Divalent copper(II) metal was chosen in the LDH synthesis because it has advantages compared to other metals such as low resistance, active sites derived from $\mathrm{Cu}^{2+}$ metal and copper ion dispersion which will result in good adsorption performance. Furthermore, $\mathrm{CuAl}-\mathrm{LDH}$ was composited with hydrochar from rambutan peel (Nephelium lappaceum L). The synthesized materials were characterized using XRD, FT-IR, and SEM analysis. The material will be applied as an adsorbent by influencing the adsorption selectivity of mixed dyes, 
adsorption isotherms, adsorption thermodynamics and regeneration studies of each adsorbent.

\section{Materials and Methods}

\subsection{Materials}

The reagents used for the manufacture of $\mathrm{CuAl}-\mathrm{LDH}$ s are copper(II) nitrate $\left(\mathrm{Cu}\left(\mathrm{NO}_{3}\right)_{2} \cdot 3 \mathrm{H}_{2} \mathrm{O}, \quad \mathrm{MW}=241.60 \mathrm{~g} / \mathrm{mol}\right.$, purity $\geq 98 \%$ ) by LOBA Chemie, aluminum(III) nitrate, $\left(\mathrm{Al}\left(\mathrm{NO}_{3}\right)_{3} .9 \mathrm{H}_{2} \mathrm{O}, \quad \mathrm{MW}=375.13 \mathrm{~g} / \mathrm{mol}\right.$, purity $\geq 98 \%$ ) by Sigma Aldrich, iron(II) chloride $\left(\mathrm{FeCl}_{2} .4 \mathrm{H}_{2} \mathrm{O}, \quad \mathrm{MW}=198.83 \mathrm{~g} / \mathrm{mol}\right.$, purity $\geq 99 \%$ ) by Merck, hydrochloric acid ( $\mathrm{HCl}$, $\mathrm{MW}=36.458 \mathrm{~g} / \mathrm{mol}, 37 \%$ ), sodium hydroxide $(\mathrm{NaOH}, \mathrm{MW}=40.00 \mathrm{~g} / \mathrm{mol}$ by Merck, and the basic ingredient of hydrochar is rambutan peel.

\subsection{Methods}

\subsubsection{Hydrothermal carbonization}

Hydrothermal carbonization [29] experiments were carried out using $2.5 \mathrm{~g}$ of rambutan peel (Nephelium lappaceum L.) then added with $50 \mathrm{~mL}$ of distilled water which was put into a stainless steel autoclave hydrothermal device and sealed. The autoclave has a high pressure heating system according to the literature of Akarsu et al. [30]. The autoclave reaches a temperature of $200{ }^{\circ} \mathrm{C}$ for 10 hours. At the end of the process, the autoclave tool is at room temperature and the product in the autoclave is filtered to separate the filtrate and residue through filter paper. The solid (hydrochar/HC) was dried at $105{ }^{\circ} \mathrm{C}$ for 24 hours. the mechanism preparation of hydrothermal carbonization was shown in Figure 1.

\subsubsection{Synthesis CuAl-LDHs}

$\mathrm{CuAl}-\mathrm{LDH}$ was synthesized using the coprecipitation method [27] by mixing $100 \mathrm{~mL}$ $(0.75 \mathrm{M})$ copper(II) nitrate with $100 \mathrm{~mL}$ aluminum(II) nitrate $(0.25 \mathrm{M})$. The mixture was stirred and $1 \mathrm{M} \mathrm{NaOH}$ solution was added dropwise until the mixture reached $\mathrm{pH} 10$. The mixture was heated at $80{ }^{\circ} \mathrm{C}$ and maintained for 20 hours. The final process is carried out by separating the product using a vacuum, then the filtrate is dried at a temperature of $50{ }^{\circ} \mathrm{C}$ to dry.

\subsubsection{Preparation modified CuAl-LDH}

The modification of $\mathrm{CuAl}-\mathrm{LDHs}$ into $\mathrm{CuAl}$ HC LDH composites was prepared using the coprecipitation method, namely precipitation using an alkaline solution ( $\mathrm{KOH}$ or $\mathrm{NaOH}$ ). The preparation process was made with $30 \mathrm{~mL}$ $(0.75 \mathrm{M})$ copper(II) nitrate with $30 \mathrm{~mL}(0.25 \mathrm{M})$ aluminum(III) nitrate mixed and stirred and kept for 1 hour until a gel was formed. The CuAl-LDHs gel mixture was added by slowly dripping $2 \mathrm{M} \mathrm{NaOH}$ solution until it reached $\mathrm{pH}$ 10. The gel mixture was added with $3 \mathrm{~g}$ of hydrochar from rambutan peel then the solution was stirred and kept at $80^{\circ} \mathrm{C}$ for 3 days. The product from the preparation process was filtered to obtain a precipitate, the precipitate was rinsed with distilled water, and the resulting product was dried at $50^{\circ} \mathrm{C}$ for 24 hours.

\subsubsection{Adsorption experiment}

The first experiment was to parameterize the adsorption selectivity of a mixture of several dyes, namely malachite green (MG), methylene blue (MB), rhodamine-B (Rh-B), methyl orange (MO), and methyl red (MR). The dye selectivity process is carried out by mixing 100 $\mathrm{mL}$ of each dye with the same concentration $(10 \mathrm{mg} / \mathrm{L})$ which is put into a $500 \mathrm{~mL}$ beaker, then the dye mixture is homogenized and after being homogeneous, take $50 \mathrm{~mL}$ of the solution. The mixture was put into a beaker and added as much as $0.05 \mathrm{~g}$ of adsorbent. The beaker containing the adsorbent and solution was then placed on a shaker to carry out the adsorption selectivity process by varying the adsorption contact time from $0,15,30,60$ to 120 minutes. the final process after the adsorption process, the mixture was separated by a centrifugation process to obtain the filtrate and residue, then the filtrate was analyzed using a UV-Vis spectrophotometer to scan the wavelength of the dye mixture solution.

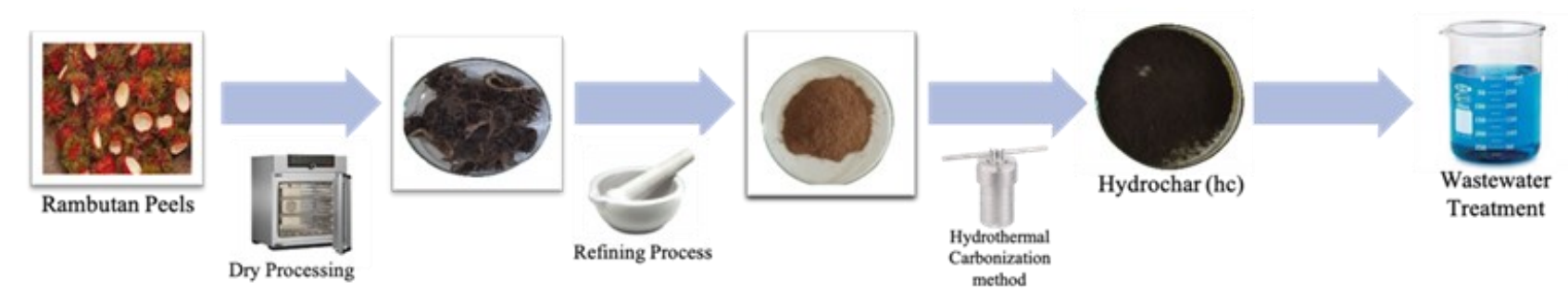

Figure 1. Mechanism of preparation and application of materials 
The second experiment, isotherm and thermodynamic parameters by influencing variations in the initial concentration of dye by varying the temperature in the adsorption process with the following treatment in this study using variations in dye concentration $(60,70,80$, 90 and $100 \mathrm{mg} / \mathrm{L}$ ), taken $20 \mathrm{~mL}$ was put into a beaker and $0.02 \mathrm{~g}$ of adsorbent was added, then the temperature was varied $(303,313,323$, and $333 \mathrm{~K})$. The mixture was stirred for 2 hours and maintained at various temperatures used during the adsorption process.

The third experiment is the study of regeneration. But before the regeneration process must be carried out the desorption process first. In this study, $50 \mathrm{~mL}$ of methylene blue solution $(50 \mathrm{mg} / \mathrm{L})$ was put into a beaker and added $0.5 \mathrm{~g}$ of adsorbent, then stirred for 2 hours using a shaker. Then, when finished, separate the filtrate and residue. The absorbance value of the filtrate was measured using a UV-Vis Spectrophotometer and dried the residue remaining from the adsorption process at $40{ }^{\circ} \mathrm{C}$. After the adsorbent is dry, take $0.01 \mathrm{~g}$ and add it to a solution of $10 \mathrm{~mL}$ of water that has been put in a beaker and place it on an ultrasonic device for 2 hours for the desorption process, separate the filtrate and residue, then dry the residue at $40{ }^{\circ} \mathrm{C}$. Then, The regeneration process was carried out using a dry adsorbent that had gone through the desorption process, 50 $\mathrm{mL}$ of methylene blue solution $(100 \mathrm{mg} / \mathrm{L})$ was added to the dry adsorbent and stirred for 2 hours. The mixture was separated between residue and filtrate, the filtrate was taken and measured using a UV-Vis spectrophotometer, while the residue from the separation was dried and then used for the desorption process again with water. The dry adsorbent that has gone through the desorption process is then reused for the regeneration process. The process was carried out for seven cycles with the same treatment.

\subsubsection{Characterization}

CuAl-LDHs, HC, and CuAl-HC composites were characterized by FT-IR spectroscopy (Shimadzu FT-IR Prestige-21). The morphology of the material was determined by SEM characterization. The powder material was characterized by XRD using a diffactometer (Rigaku Miniflex-600) with monochromatic radiation of $\mathrm{Cu}-\mathrm{Ka}$ in the range $(2 \theta) 5-60^{\circ}$ with a scanning speed of $2 \% \mathrm{~min}$. MB was analyzed using UVVisible Spectrophotometer (Biobase BK-UV 1800 PC), and measured at a maximum absorbance wavelength of about $664 \mathrm{~nm}$.

\section{Results and Discussion}

First, XRD technique was used to confirm the crystallographic structure of CuAl-LDHs, $\mathrm{HC}$ and composites modified by $\mathrm{CuAl}-\mathrm{LDHs}$ with hydrochar (HC) obtained after using the coprecipitation method. As shown in Figure 2, Diffractograms of $\mathrm{CuAl}-\mathrm{LDH}, \mathrm{HC}$ and $\mathrm{CuAl}-$ HC composites are seen with sharp Bragg reflections and peaks observed at an angle of $2 \theta$ ranging from $5-80^{\circ}$ For CuAl-LDHs, it has sharp peaks at an angle of $2 \theta=11.72^{\circ}, 23.51^{\circ}$ and $35.59^{\circ}$, which can be attributed to the crystal planes of (003), (006) and (009) of pure CuAl-LDHs according to JCPDS No.36-0630 [31]. According to Szabados et al. [32] reflections at (012) indicate compounds $\mathrm{M}^{2+}(\mathrm{OH})_{2}$ and $\mathrm{M}^{3+}(\mathrm{OH})_{3}$, where (009) indicates byproduct
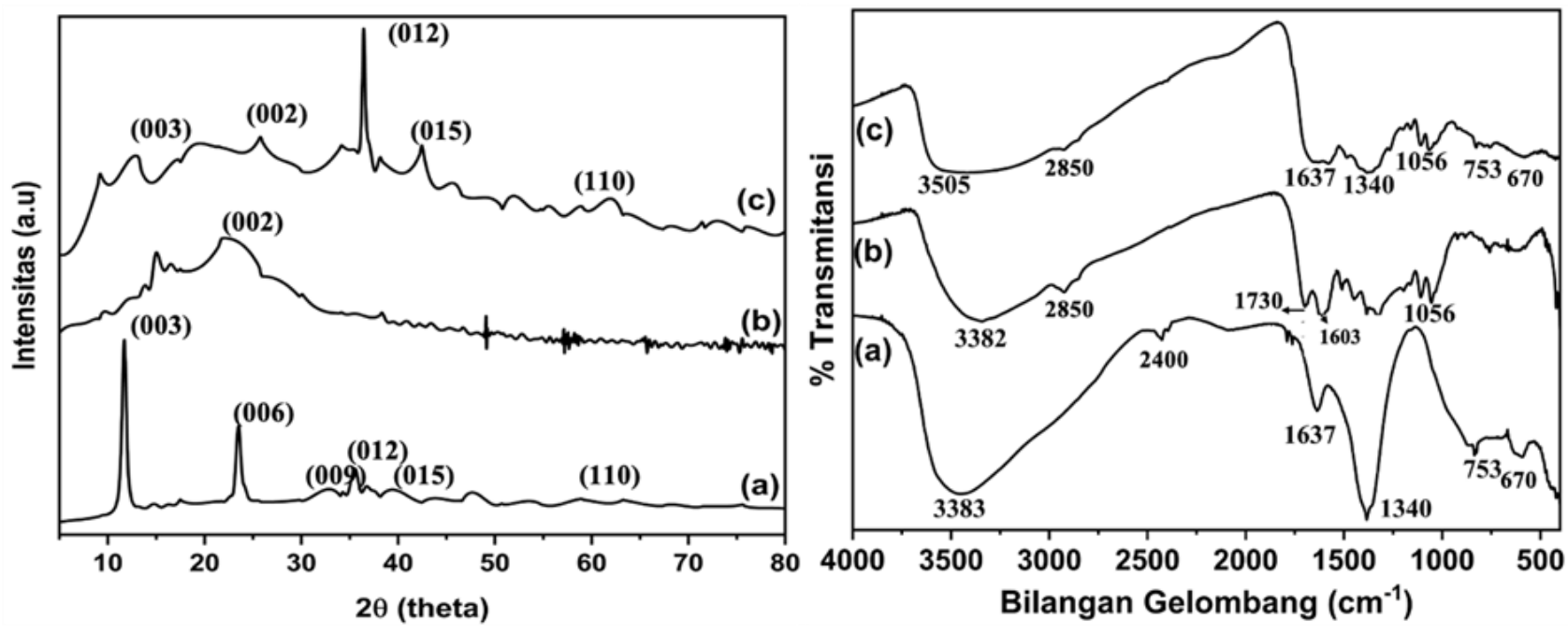

Figure 2. X-ray Powder diffraction patterns and spectrum FT-IR of CuAl-LDHs (a) HC(b) and Composite $\mathrm{CuAl}-\mathrm{HC}(\mathrm{c})$. 
compounds in LDHs, such as carbonate anions, nitrates, present in the interlayer or mixtures of metal oxides that cause peaks in the LDHs reflection (009) amorphous. This phenomenon indicates that a layered double hydroxide layered structure was successfully formed. According to Palapa et al. [27], the characteristic of the CuAl-LDHs diffraction pattern that appears has high crystallinity and the formation of hydrotalcite. The modified $\mathrm{CuAl}-\mathrm{HC}$ composite was seen to have a decreased intensity and a widening peak indicating that the crystallinity was decreased. This is triggered by the modification of $\mathrm{LDH}$ with $\mathrm{HC}$, where $\mathrm{HC}$ has amorphous characteristics shown at an angle of $2 \theta$, which is $22^{\circ}(002)$ [33]. In addition, $\mathrm{CuAl}-\mathrm{HC}$ showed an XRD pattern similar to pure $\mathrm{CuAl}$ LDHs, this proves that the modified treatment by composited $\mathrm{LDH}$ with $\mathrm{HC}$ did not change the layer structure of $\mathrm{LDH}$.

The FTIR is spectrum shown in Figure 2. is the spectrum of $\mathrm{CuAl}-\mathrm{LDHs}, \mathrm{HC}$, and $\mathrm{CuAl} / \mathrm{HC}$ materials. It can be seen in the figure that $\mathrm{CuAl}-\mathrm{LDH}$ has a peak width of about $3382 \mathrm{~cm}^{-1}$ which is related to the $\mathrm{OH}$ vibration of the hydrogen bonded metal on the surface of the layer, the peak around $2400 \mathrm{~cm}^{-1}$ is related to the vibration of $\mathrm{CO}_{2}$ gas present during the synthesis and $1637 \mathrm{~cm}^{-1}$ shows the vibration $\mathrm{H}-\mathrm{OH}$
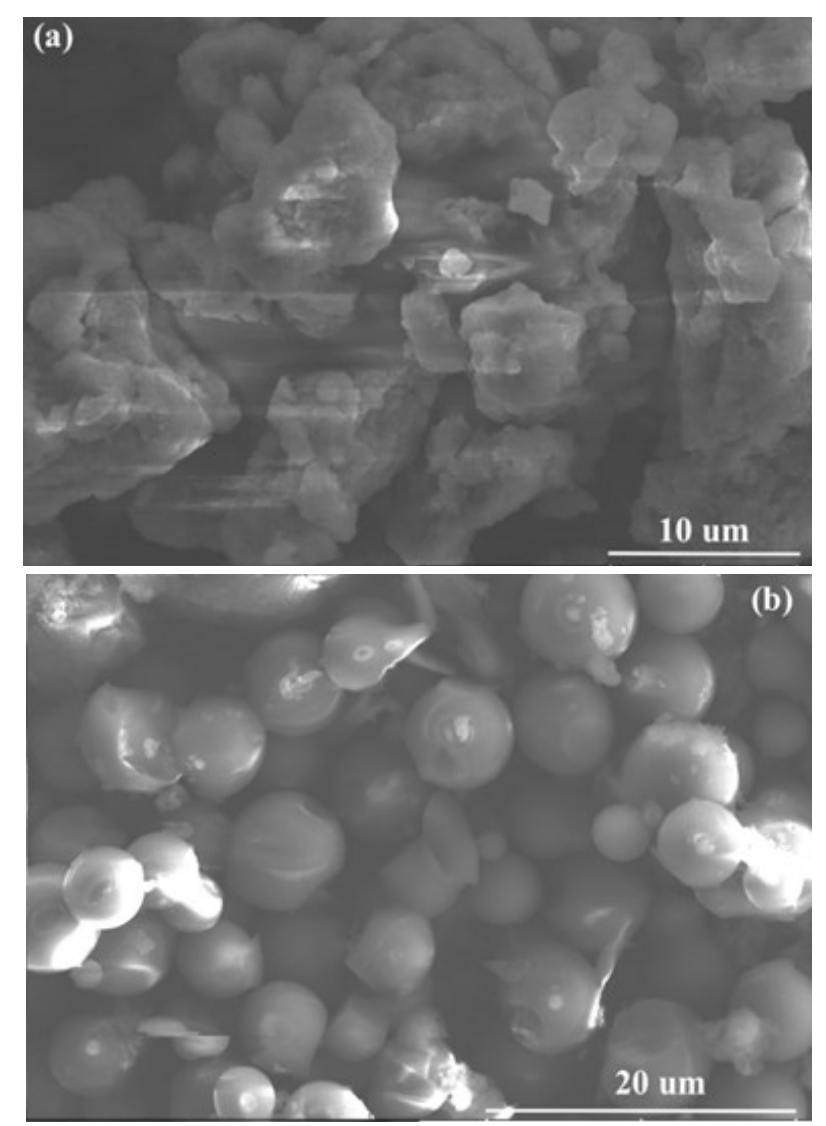

water molecules present in the interlayer [13], $1340 \mathrm{~cm}^{-1}$ associated with the nitrate anion present in the interlayer $\left(\mathrm{NO}_{3}\right.$ ion), the vibration at the peak of about $753 \mathrm{~cm}^{-1}$ and $670 \mathrm{~cm}^{-1}$ associated with oxygen-bound metal in the framework of $\mathrm{LDHs}(\mathrm{Cu}-\mathrm{O}, \mathrm{Al}-\mathrm{O}, \mathrm{Cu}-\mathrm{O}-\mathrm{Cu}$, $\mathrm{Al}-\mathrm{O}-\mathrm{Al}, \mathrm{O}-\mathrm{Cu}-\mathrm{O}$ and $\mathrm{O}-\mathrm{Al}-\mathrm{O})$. The peak is around $500 \mathrm{~cm}^{-1}$ which indicates the presence of metal hydroxides in the LDH layer [34]. Figure 2 shows that the spectrum of hydrochar has a peak of about $3383 \mathrm{~cm}^{-1}$ associated with the vibration of water molecules and a peak around $2850 \mathrm{~cm}^{-1}$ indicating the aliphatic $\mathrm{C}-\mathrm{H}$ group vibration, the vibration peak of around $1730 \mathrm{~cm}^{-1}$ and $1607 \mathrm{~cm}^{-1}$ associated with the vibration of the $\mathrm{C}=\mathrm{O}$ group, and $1056 \mathrm{~cm}^{-1}$ associated with the vibration of the $\mathrm{C}=\mathrm{C}$ group. The modified material, namely the $\mathrm{CuAl}-\mathrm{HC}$ composite, has a vibration similar to that of pure LDH and HC. The presence of these various vibrational peaks confirms the successful modification of $\mathrm{LDH}$ with $\mathrm{HC}$.

Figure 3 analyzes the material prepared from $\mathrm{CuAl}-\mathrm{LDH}$, $\mathrm{HC}$ and modified pure $\mathrm{LDH}$ with $\mathrm{HC}$ to $\mathrm{CuAl}-\mathrm{HC}$ using an SEM that aims to see the surface morphology of the material obtained through scanning electron microscopy (SEM). The encapsulated powder is shown in Figure 3. Figure 3(a) shows that the LDH adsorbent has a rough, uneven surface texture and irregular pores. In contrast to the $\mathrm{HC}$ shown in Figure 3(b), the surface morphology of the HC prepared using the hydrothermal carbonization (HTC) method looks shaped like balls measuring $(1-10 \mu \mathrm{m})$. Figure 3(c) shows the morphology of the CuAl-HC composite material which shows an uneven and rough surface.

The selectivity of dyes on each adsorbent $\mathrm{CuAl}-\mathrm{LDH}$, $\mathrm{HC}$, and CuAl-HC was carried out by measuring the maximum wavelength of a mixture of dye solutions of MG, MB, Rh-B, MR,

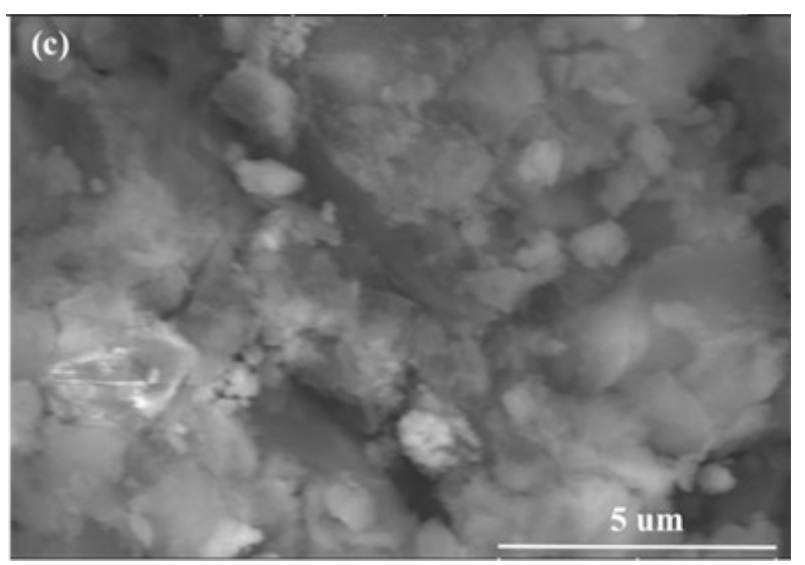

Figure 3. SEM image of CuAl-LDHs (a) HC(b) and Composite CuAl-HC(c). 
$\mathrm{CR}$ and $\mathrm{MO}$ without the influence of $\mathrm{pH}$ using a UV-UV spectrophotometer. Vis in the wavelength range between $400-700 \mathrm{~nm}$. The results of the measurement of the wavelength at the maximum absorbance are shown in Figure 4. The selectivity of adsorption on the dye mixture can be seen from the change in the wavelength of the maximum absorbance during the adsorp-
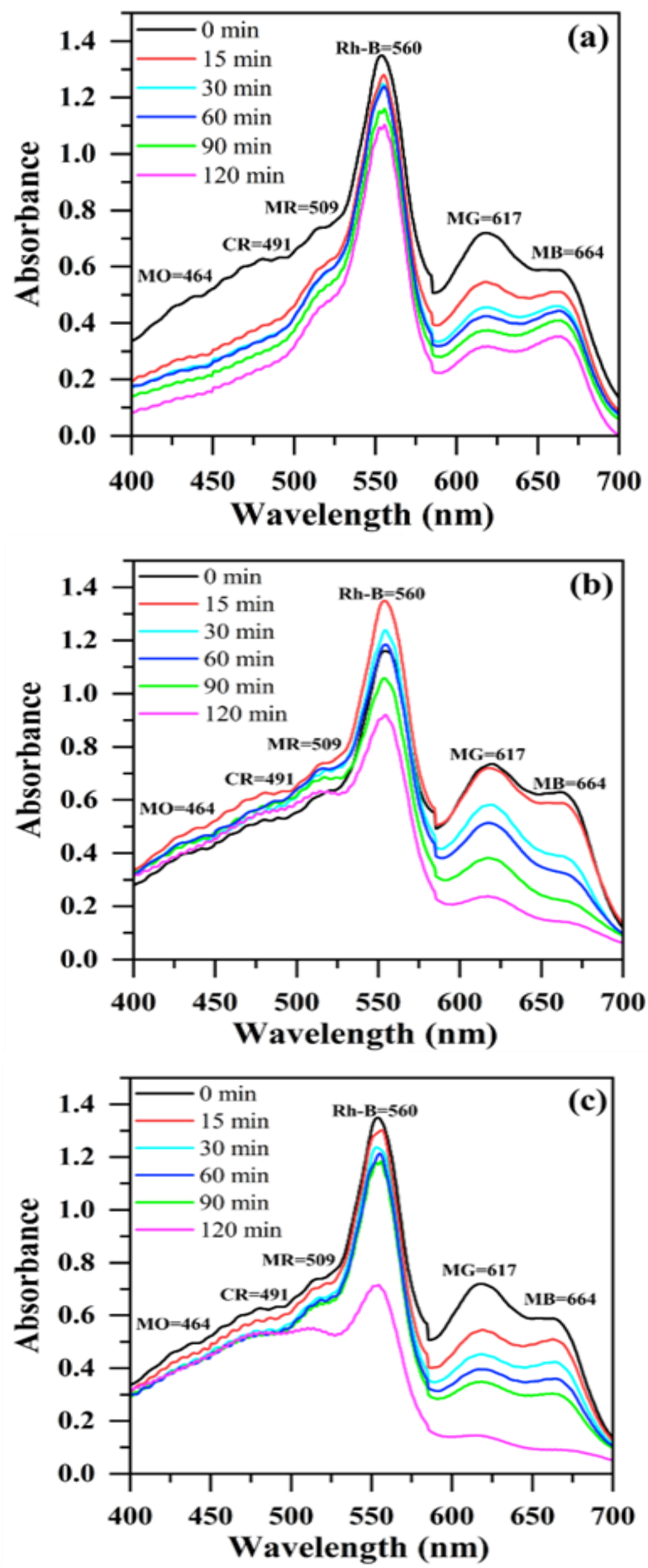

Figure 4. UV-Visible spectra of mixture MB, MG, Rh-B, MR, CR, and MO on CuAl-LDHs (a), $\mathrm{HC}(\mathrm{b})$, and $\mathrm{CuAl}-\mathrm{HC}(\mathrm{c})$. tion process according to variations in time. Figure 4 shows that the absorbance of $\mathrm{CuAl}$ LDHs, HC and CuAl-HC adsorbents decreased with increasing adsorption contact time. Among these dye mixtures, MB dye was seen for $\mathrm{CuAl}-\mathrm{LDH}$, $\mathrm{HC}$, and $\mathrm{CuAl}-\mathrm{HC}$ adsorbents more adsorbed than MG, Rh-B, MR, CR and MO. A drastic decrease in absorbance value oc-
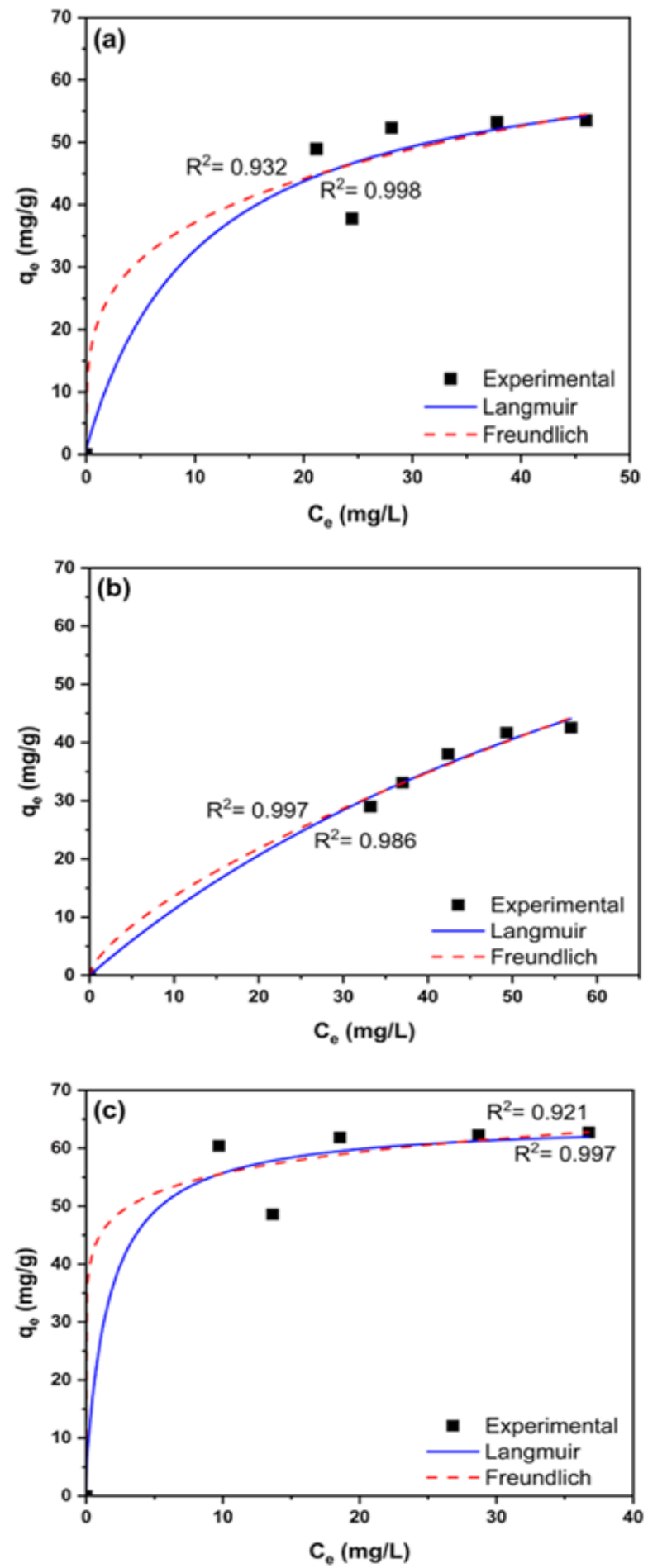

Figure 5. Adsorption isotherm model of $\mathrm{MB}$ using $\mathrm{CuAl-LDHs}$ (a), $\mathrm{HC}$ (b), and CuAl-HC (c). 
curred at 120 minutes with the adsorbed reaching $9.465 \mathrm{mg} / \mathrm{g}$ for $\mathrm{CuAl}-\mathrm{HC}$ adsorbent, while $\mathrm{CuAl}-\mathrm{LDHs}$ and $\mathrm{HC}$ reached $3.876 \mathrm{mg} / \mathrm{g}$ and $8.234 \mathrm{mg} / \mathrm{g}$, respectively. After knowing the most selective MB dye, the MB dye continued to the isotherm adsorption and thermodynamic adsorption process which looks like Figure 5.

Adsorption study with adsorption isotherm treatment was carried out by varying the initial concentration of MB by varying the adsorption temperature. Determining the Langmuir and Freundlich adsorption isotherm model determined according to the equation based on the literature $[22,35]$. The isotherm parameters are obtained from the Langmuir and Freundlich equations. Langmuir and Freundlich isotherm equations are as follows:

Langmuir : $\frac{C}{m}=\frac{1}{b K_{M L}}+\frac{C}{b}$

Freundlich : $\log q_{e}=\log K_{F}+\frac{1}{n} \log C_{e}$

where $C$ is a saturated concentration of adsorbate, $m$ is the amount of adsorbate, $b$ is the maximum adsorption capacity (mg.g $\left.{ }^{-1}\right), K_{M L}$ is the Langmuir constant $\left(\mathrm{L}^{\mathrm{mg}} \mathrm{m}^{-1}\right), q_{e}$ is adsorption capacity at equilibrium (mg.g $\left.{ }^{-1}\right), C_{e}$ is a concentration of adsorbate at equilibrium (mg.L-1), $K_{F}$ is Freundlich constant.

Determination of the isotherm model of an adsorption process can be determined based on the linear regression value $R^{2}>0.932$ (which is close to 1). Figure 5 shows the profile of the Langmuir and Freundlich isotherm model. Figure 5 shows that Figure 5(a) is $\mathrm{CuAl} \mathrm{LDH}$ and $5(b)$ is HC, each of which has a smaller adsorption capacity $\left(q_{e}(\mathrm{mg} / \mathrm{g})\right.$ compared to Figure 5(c) which is a $\mathrm{CuAl}-\mathrm{HC}$ composite that has a larger adsorption capacity so that it can be seen from the curve of Figure $5 \mathrm{CuAl} \mathrm{LDH}$ and $\mathrm{HC}$ look lower. It can be seen that MB adsorbed with $\mathrm{CuAl}-\mathrm{LDH}, \mathrm{HC}$ and $\mathrm{CuAl}-\mathrm{HC}$ tends to have a $\mathrm{R}^{2}$ value closer to 1 , namely the Langmuir isotherm model. This is supported by the calculated data presented in Table 1.

From Table 1 it can be seen that the Langmuir Isotherm calculates the Langmuir constant $\left(k_{L}\right)$, and shows the suitability of the model for the adsorption system. If the $k_{L}$ value is between 0 and 1 , the system is considered suitable for adsorption [36] and Table 1 shows the results which are in the range of 0.293; $0.080 ; 0.074$. Furthermore, the adsorption isotherm data is also equipped with the Freundlich equation with parameters $k_{F}$ and $\mathrm{n}$ which indicate the preference of the adsorbent/adsorbate system, where the value of $k_{F}$ is a constant for the system, which is related to the binding energy [5] and the adsorption capacity of Freundlich $\left(k_{F}\right)$ according to with data obtained respectively $19.843 ; 4.870 ; 0.920$ for $\mathrm{CuAl}-\mathrm{LDH}, \mathrm{HC}$ and $\mathrm{CuAl}-\mathrm{HC}$, while the adsorption intensity represented by the value of $n$ indicates the suitability of the adsorption isotherm model for adsorption if the value of $n$ is above 1. From Table 1 it can be seen that the value of $\mathrm{n} \mathrm{CuAl}-\mathrm{LDH}, \mathrm{HC}$ and $\mathrm{CuAl}-\mathrm{HC}$ each of $3.792 ; 4.651 ; 10.560$.

According to the literature Araújo et al. [12], the adsorption process with a tendency to follow the Langmuir isotherm model shows that the adsorption that occurs is the formation of a monolayer and the weak force or interaction between the adsorbent and the adsorbate is the result of physical interaction. The Langmuir model is based on the assumption that it has the same active site so that the surface is homogeneous and the coverage of monolayer formation is without interactions between the adsorbed molecules [37]. In addition to determining the adsorption isotherm model, the data in Table 1 presents the maximum capacity. The use of different adsorbents for MB dye causes different adsorption capacities in each process according to the capacity or ability of the adsorbent. MB adsorption process using modified adsorbent, namely CuAl-HC composite has a maximum adsorption capacity of $175.439 \mathrm{mg} / \mathrm{g}$ while pure LDH material reaches $57.803 \mathrm{mg} / \mathrm{g}$. The modified capacity had the adsorption capacity which increased drastically by increasing threefold from the pure LDH.

The comparison of MB absorption for several adsorbents is presented in Table 2. Table 2 shows that the adsorption capacity of several adsorbents for MB dye and the comparison using the prepared adsorbents in the form of

Table 1. Isotherm model of MB adsorption on CuAl-LDHs, HC and CuAl-HC.

\begin{tabular}{lccccc}
\hline \multirow{2}{*}{ Materials } & \multicolumn{2}{c}{ Langmuir } & & \multicolumn{2}{c}{ Freundlich } \\
\cline { 2 - 3 } \cline { 5 - 6 } & $q_{m}(\mathrm{mg} / \mathrm{g})$ & $k_{L}$ & & $n$ & $k_{F}$ \\
\hline $\mathrm{CuAl} \mathrm{LDH}$ & 57.803 & 0.293 & & 3.792 & 19.843 \\
$\mathrm{HC}$ & 49.286 & 0.080 & & 4.651 & 4.870 \\
$\mathrm{CuAl} \mathrm{LDH}-\mathrm{HC}$ & 175.439 & 0.074 & & 10.560 & 0.921 \\
\hline
\end{tabular}


$\mathrm{CuAl}-\mathrm{LDHs}, \mathrm{HC}$ and $\mathrm{CuAl}-\mathrm{HC}$ in the study. MB adsorption capacity for $\mathrm{CuAl}-\mathrm{LDHs}, \mathrm{HC}$ and $\mathrm{CuAl}-\mathrm{HC}$ adsorbents has a greater adsorption capacity than other adsorbents and it can be seen that the modified CuAl-LDH material has a greater adsorption capacity for MB adsorption.
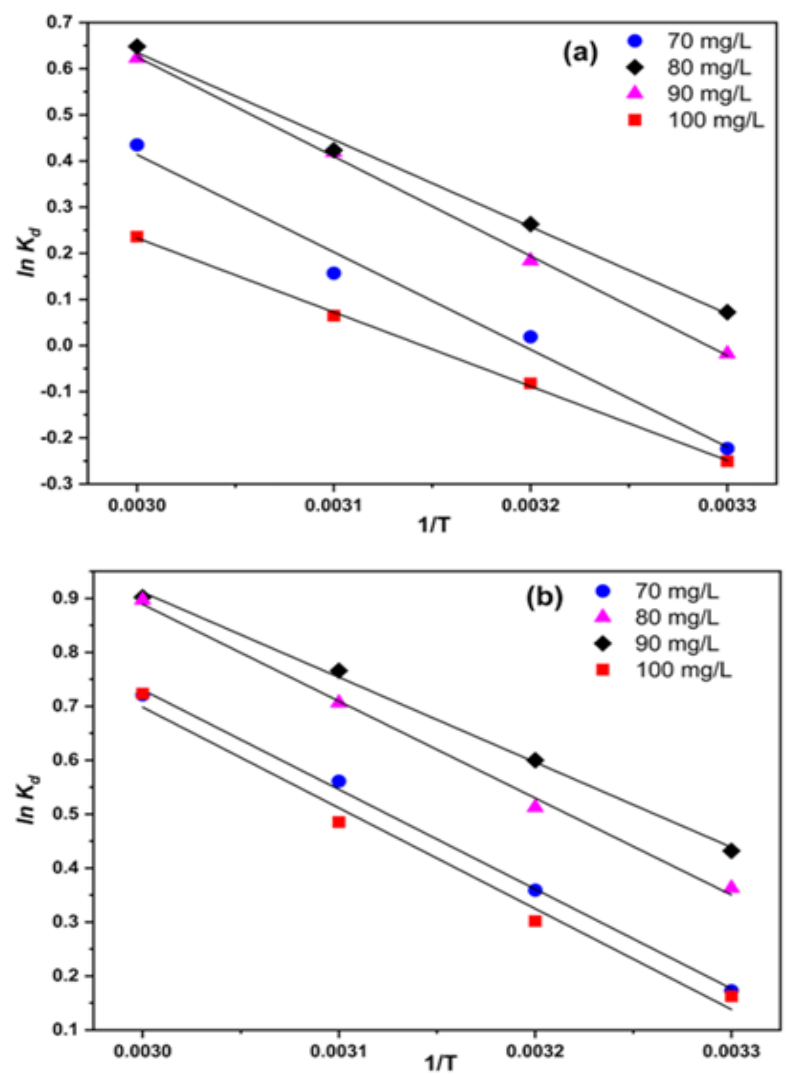

Thermodynamic parameters related to the change in Gibbs free energy $\left(\Delta G^{\circ}\right)$, enthalpy change $\left(\Delta \mathrm{H}^{\circ}\right)$, and entropy change $\left(\Delta \mathrm{S}^{\circ}\right)$ can be calculated using the Van't Hoff equation as follows [42].

$$
\begin{aligned}
& \Delta G=-R T \ln K_{d} \\
& \ln K_{d}=\frac{\Delta S}{R}-\frac{\Delta H}{R T}
\end{aligned}
$$

$K_{d}$ is the solute distribution coefficient $(\mathrm{L} / \mathrm{g}), \mathrm{R}$ is the universal gas constant $(8.314 \mathrm{~mol} / \mathrm{K}), \mathrm{T}$ is temperature (K), Gibbs free energy $\left(\Delta \mathrm{G}^{\circ}\right.$, $\mathrm{kJ} / \mathrm{mol})$, entropy $\left(\Delta \mathrm{S}^{\circ}, \mathrm{kJ} / \mathrm{mol}\right)$, and enthalpy $\left(\Delta \mathrm{H}^{\circ}, \mathrm{J} / \mathrm{mol} . \mathrm{K}\right)$.

The plot of $\ln K_{d}$ vs $1 / \mathrm{T}$, is shown in Figure 6. The thermodynamic parameter values obtained from the slope and intercept of the van't Hoff plot are shown in Table 3. The appropriate van't Hoff plot is used to calculate

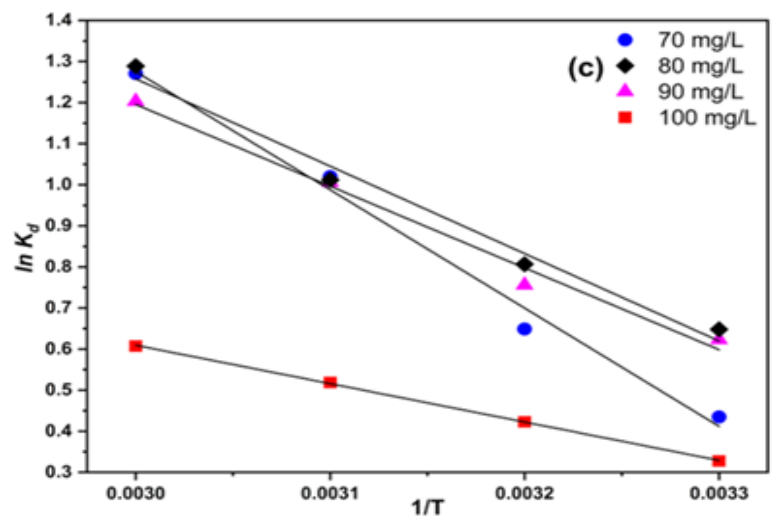

Figure 6. Van't Hoff plot for adsorption of MB on CuAl-LDHs (a), HC (b), and CuAl-HC (c).

Table 2. Comparison of several adsorbents to removal MB.

\begin{tabular}{lcc}
\hline Adsorbent & Adsorption Capacity $(\mathrm{mg} / \mathrm{g})$ & Reference \\
\hline 3D-MgAl-LDH & 54.3 & {$[38]$} \\
NiFeTi $-\mathrm{LDH}$ & 29.940 & {$[39]$} \\
Zn-Fe LDH & 32.894 & {$[40]$} \\
Mn-Fe LDH & 43.103 & {$[40]$} \\
Activated Carbon from Coconut Shell & 15.423 & {$[19]$} \\
Activated Carbon developed from Ficus carica bast & 47.62 & {$[41]$} \\
Organo/ZnAl-LDH Nanocomposite & 113 & {$[13]$} \\
CuAl-LDHs & 57.803 & In this study \\
HC & 49.286 & In this study \\
CuAl-HC & 175.439 & In this study \\
\hline
\end{tabular}

\begin{tabular}{|c|c|c|c|c|}
\hline \multirow{2}{*}{ Parameters } & \multirow{2}{*}{$\mathrm{T}(\mathrm{K})$} & \multicolumn{3}{|c|}{ Materials } \\
\hline & & $\mathrm{CuAl} \mathrm{LDH}$ & $\mathrm{HC}$ & $\mathrm{CuAl} \mathrm{LDH}-\mathrm{HC}$ \\
\hline \multirow[t]{4}{*}{$\Delta \mathrm{G}^{\circ}$} & 303 & -0.343 & -0.430 & -0.368 \\
\hline & 313 & -0.980 & -0.956 & -0.739 \\
\hline & 323 & -1.617 & -1.481 & -1.109 \\
\hline & 333 & -2.254 & -2.007 & -1.479 \\
\hline \multicolumn{2}{|c|}{$\Delta \mathrm{S}^{\circ}$} & 0.064 & 0.053 & 0.037 \\
\hline \multicolumn{2}{|c|}{$\Delta \mathrm{H}^{\circ}$} & 18.963 & 15.503 & 10.851 \\
\hline
\end{tabular}

Table 3. Thermodynamic parameters of MB adsorption on CuAl-LDHs, HC and CuAl-HC. 
the thermodynamic parameters using the slope and intercept equations van't Hoff [43] to determine the thermodynamic properties of adsorption.

The thermodynamic parameters yielded the data shown in Table 3. Data $\Delta \mathrm{H}^{\circ}$ (enthalpy), $\Delta \mathrm{S}^{\circ}$ (entropy), $\Delta \mathrm{G}^{\circ}$ (Gibbs free energy) were obtained from the equation according to the literature [44]. Table 3 shows the results with negative values for $\Delta \mathrm{G}^{\circ}$ in all adsorption temperature ranges used. $\Delta \mathrm{G}^{\circ}$ increased with adsorption temperature. Increasing the $\Delta \mathrm{G}^{\circ}$ value with increasing adsorption temperature, the $\Delta \mathrm{G}^{\circ}$ values are in the range of $-0.343 \mathrm{~kJ} / \mathrm{mol}$ to $-2.254 \mathrm{~kJ} / \mathrm{mol}(\mathrm{CuAl} \mathrm{LDH}),-0.430 \mathrm{~kJ} / \mathrm{mol}$ to $-2.007 \mathrm{~kJ} / \mathrm{mol}(\mathrm{HC})$, and $-0.368 \mathrm{~kJ} / \mathrm{mol}$ to $-1.479 \mathrm{~kJ} / \mathrm{mol}$ (CuAl-HC), this indicates that there is a tendency to decrease the degree of adsorption feasibility of $\mathrm{MB}$ [45]. A negative value at $\Delta \mathrm{G}^{\circ}$ indicates that the adsorption process is spontaneous [46,47]. According to Batool et al. [48], the value of $\Delta \mathrm{G}^{\circ}$ decreases with increasing temperature. Reflecting that the adsorption that occurs is better at high temperatures. If the value of $\Delta \mathrm{H}^{\circ}$ has a range of -20 to $40 \mathrm{~kJ} / \mathrm{mol}$ then the adsorption tends to be physical adsorption and in the range of 80 to 400 $\mathrm{kJ} / \mathrm{mol}$ then the adsorption tends to be chemical adsorption. In this study, the $\Delta \mathrm{H}^{\circ}$ value showed a range of $10.851 \mathrm{~kJ} / \mathrm{mol}$ to 18.963 $\mathrm{kJ} / \mathrm{mol}$ with a physical adsorption tendency $[49,50] . \Delta \mathrm{H}^{\circ}$ is positive, this indicates that MB adsorption is endothermic and positive for $\mathrm{S}^{\circ}$ with a value of $0.064 \mathrm{~J} / \mathrm{mol} . \mathrm{K}$ to $0.037 \mathrm{~J} / \mathrm{mol} . \mathrm{K}$ because the randomness during the adsorption process increases due to the solid-liquid interaction that occurs in the adsorption [51].

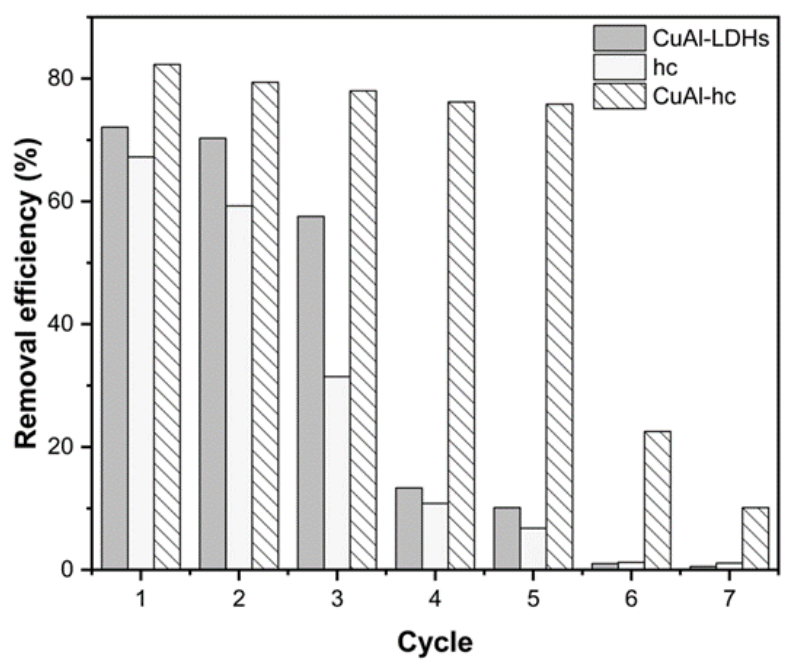

Figure 7. CuAl-LDHs, $\mathrm{HC}$ and $\mathrm{CuAl}-\mathrm{HC}$ adsorbent regeneration ability.
The ability of the adsorbent to overcome contamination was also tested for the effectiveness of the ability of the adsorbent for the regeneration process in reuse. The regeneration process of $\mathrm{CuAl}-\mathrm{LDHs}, \mathrm{HC}$, and $\mathrm{CuAl}-\mathrm{HC}$ adsorbents was carried out for 7 repetition cycles, which is presented in Figure 7.

The test results for the regeneration process of $\mathrm{CuAl}-\mathrm{LDH}, \mathrm{HC}$ and $\mathrm{CuAl}-\mathrm{HC}$ adsorbents to overcome dye pollution are presented in Figure 7. The results show that the modified CuAl$\mathrm{LDH}$ material has advantages over pure $\mathrm{LDH}$, this is evidenced by the higher adsorption capacity, stability for the adsorbent reuse process and has more absorption capacity which is supported by the active group factor possessed by the $\mathrm{CuAl}-\mathrm{HC}$ composite material which is supported by the FT-IR characterization, where the CuAl-HC composite has more functional groups due to the combination of functional groups of pure $\mathrm{CuAl} \mathrm{LDH}$ and $\mathrm{HC}$ materials. MB adsorption using CuAl-LDH modified material is stable for five regeneration cycles, this is due to the process of modifying $\mathrm{LDH}$ with composites or combining two materials such as LDH with hydrochar which can increase the active site of the material and structural stability because there is the protection of the $\mathrm{LDH}$ layer from hydrochar so that there is no peeling LDH layer and structural damage [35]. The CuAl-HC composite has an adsorption capacity of $82.2 \% ; 79.3 \% ; 77.9 \%$; $76.1 \% ; 75.8 \%$, while $\mathrm{CuAl} \mathrm{LDH}$ had an unstable adsorption capacity of $72.09 \%$ and decreased to $10.12 \%$, HC had an adsorption capacity of $67.23 \%$ and decreased to $6.76 \%$. So it can be concluded that the modification of LDH with hydrochar has a good regeneration ability.

\section{Conclusion}

Based on the data characterization of $\mathrm{CuAl}$ LDH modified layered double hydroxide with composite with hydrochar (HC) to form $\mathrm{LDH}$ CuAl-HC by XRD, FT-IR and SEM analysis, the material was successfully produced which was shown by the appearance of peaks and vibrations similar to pure $\mathrm{LDH}$ and $\mathrm{HC}$. CuAlHC LDH was applied as adsorbent for methylene blue adsorption. CuAl-HC LDH adsorption isotherm data showed that the adsorption process tended to follow the Langmuir isotherm model $\left(\mathrm{R}^{2}>0.932\right)$ with a maximum adsorption capacity of $175.439 \mathrm{mg} / \mathrm{g}$, an increase of three times from pure LDH with a maximum adsorption capacity of $57.803 \mathrm{mg} / \mathrm{g}$. The data from thermodynamic parameters showed that the adsorption was spontaneous and endother- 
mic. The effectiveness of the adsorbent for repeated use reaches five cycles as evidenced by the regeneration data and adsorption capacity of $82.2 \%, 79.3 \%, 77.9 \%, 76.1 \%$, and $75.8 \%$.

\section{Acknowledgement}

The author expresses his deepest gratitude to the Research Center of Inorganic Materials and Complexes of the Faculty of Mathematics and Natural Sciences, Sriwijaya University which has provided facilities. Thank you for the funding and support for this research from Ministry of Research, Technology, and Higher Education Republic of Indonesia for the Research 2021-2022 PDUPT Professional Grant, contact No. 150/SP2H/LT/DRPM/2021.

\section{References}

[1] Munir, M., Nazar, M.F., Zafar, M.N., Zubair, M., Ashfaq, M., Hosseini-Bandegharaei, A., Khan, S.U., Ahmad, A. (2020). Effective Adsorptive Removal of Methylene Blue from Water. ACS Omega, 5(27), 16711-16721. DOI: 10.1021/acsomega.0c01613.

[2] Fajarwati, F.I., Yandini, N.I., Anugrahwati, M., Setyawati, A. (2020). Adsorption Study of Methylene Blue and Methyl Orange Using Green Shell (Perna Viridis). Journal Sciences and Data Analysis, 1(1), 92-97. DOI: 10.20885/EKSAKTA.vol1.iss1.art.

[3] Badri, A.F., Siregar, P.M.S.B.N., Palapa, N.R., Mohadi, R., Mardiyanto, M., Lesbani, A. (2021). Mg-Al/Biochar Composite with Stable Structure for Malachite Green Adsorption from Aqueous Solutions. Bulletin of Chemical Reaction Engineering \& Catalysis, 16(1), 149160. DOI: $10.9767 /$ bcrec.16.1.10270.149-160

[4] Pathania, D., Sharma, S., Singh, P. (2017). Removal of methylene blue by adsorption onto activated carbon developed from Ficus carica bast. Arabian Journal Chemistry, 10(2017),

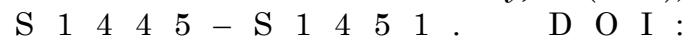
10.1016/j.arabjc.2013.04.021.

[5] Labiebah, G., Djunaidi, M. C., Haris, A., Widodo, D. S. (2019). Removal of Methylene Blue Using Used Paper Powder Ghina. Journal of Scientific \& Applied Chemistry, 22(1), 23-28. DOI: 10.14710/jksa.22.1.23-28.

[6] Mohammed, M.A., Shitu, A., Ibrahim, A. (2014). Removal of methylene blue using low cost adsorbent: a review Removal of Methylene Blue Using Low Cost Adsorbent: A Review. Research Journal of Chemical Sciences, 4(1), 91-102.
[7] Sharifi, H.S., Archin, S., Asadpour, G. (2018). Optimization of Process Parameters by Response Surface Methodology for Methylene Blue Removal Using Cellulose Dusts. Civil Engineering Journal, 4(3), 620-634. DOI: 10.28991/cej-0309121.

[8] Singh, R., Singh, T.S., Diyo, J.O.O., Smith, J.A., Edokpayi, J.N. (2020). Evaluation of Methylene Blue Sorption onto Low-Cost Biosorbents: Equilibrium , Kinetics , and Thermodynamics. Hindawi Journal of Chemistry, 2020, 8318049. DOI: $10.1155 / 2020 / 8318049$.

[9] Kuang, Y., Zhang, X., Zhou, S. (2020). Adsorption of Methylene Blue in Water onto Activated Carbon by Surfactant Modification. Water, 12(2), 587. DOI: 10.3390/w12020587.

[10] Hossain, S., Chun, D. (2020). ZnO decorated polydimethylsiloxane sponges as photocatalysts for effective removal of methylene blue dye. Materials Chemistry and Physics, 255 (July), 123589. DOI: 10.1016/j.matchemphys.2020.123589.

[11] Abdellaoui, K., Pavlovic, I., Barriga, C. (2019). Nanohybrid Layered Double Hydroxides Used to Remove Several Dyes from Water. Chemengineering Artic, 3(41), 116. DOI: .10.3390/chemengineering3020041.

[12] Araújo, C.S.T., Almeida, I.L.S., Rezende, H.C., Marcionilio, S.M.L.O., Léon, J.J.L., De Matos, T.N. (2017). Elucidation of mechanism involved in adsorption of $\mathrm{Pb}(\mathrm{II})$ onto lobeira fruit (Solanum lycocarpum) using Langmuir, Freundlich and Temkin isotherms. Microchemical Journal, 6(1), 30618-30623. DOI: 10.1016/j.microc.2017.11.009.

[13] Starukh, G., Rozovik, O., Oranska, O. (2016). Organo/Zn-Al LDH Nanocomposites for Cationic Dye Removal from Aqueous Media. Nanoscale Research Letters, 11(228), 1-10. DOI: 10.1186/s11671-016-1402-0.

[14] Lesbani, A., Palapa, N.R., Sayeri, R.J., Taher, T., Hidayati, N. (2021). High Reusability of $\mathrm{NiAl}$ LDH/Biochar Composite in the Removal Methylene Blue from Aqueous Solution. Indonesian Journal of Chemistry, 21(2), 421434. DOI: 10.22146/ijc.56955.

[15] Kundu, S., Naskar, M.K. (2021). Carbonlayered double hydroxide nanocomposite for efficient removal of inorganic and organic based water contaminants - unravelling the adsorption mechanism. Materials Advances, 2, 3600-3612. DOI: 10.1039/d1ma00064k.

[16] Murcia-salvador, A., Pellicer, J.A., Fortea, I., Vicente, M.G. (2019). Adsorption of Direct Blue 78 Using Chitosan and Cyclodextrins as Adsorbents. Polymers (Basel), 11(6), 1003. DOI: $10.3390 /$ polym 11061003 . 
[17] Tamas, A., Cozma, L., Cocheci, L., Lupa, L., Rusu, G. (2020). Adsorption of Orange II Onto Zn/Al-Layered Double Hydroxide Prepared From Zinc Ash. Frontiers in Chemistry, 8, 573535. DOI: 10.3389/fchem.2020.573535.

[18] Starukh, H., Levytska, S. (2019). The simultaneous anionic and cationic dyes removal with $\mathrm{Zn}-\mathrm{Al}$ layered double hydroxides. Applied Clay Science, 180, 105183. DOI: 10.1016/j.clay.2019.105183.

[19] Khuluk, R.H., Rahmat, A., Buhani., Suharso. (2019). Removal of Methylene Blue by Adsorption onto Activated Carbon From Coconut Shell (Cocous Nucifera L .). Indonesian Journal of Science and Technology, 4(2), 229-240. DOI: 10.17509/ijost.v4i2.18179.

[20] Palapa, N.R., Juleanti, N., Mohadi, R., Taher, T., Rachmat, A., Lesbani, A. (2020). Copper Aluminum Layered Double Hydroxide Modified by Biochar and its Application as an Adsorbent for Procion Red. Journal of Water and Environment Technology, 18(6), 359-371. DOI: $10.2965 /$ jwet.20-059

[21] Li, S., Dong, L., Wei, Z., Sheng, G., Du, K., $\mathrm{Hu}$, B. (2020). Adsorption and mechanistic study of the invasive plant-derived biochar functionalized with $\mathrm{CaAl}-\mathrm{LDH}$ for $\mathrm{Eu}(\mathrm{III})$ in water. Journal Environmental Sciences (China), 96(1), 127-137. DOI: 10.1016/j.jes.2020.05.001.

[22] Normah, N., Palapa, N.R., Taher, T., Mohadi, R., Utami, H.P., Lesbani, A. (2021). The Ability of Composite Ni/Al-carbon based Material Toward Readsorption of Iron (II) in Aqueous Solution. Science \& Technology Indonesia, 6(3), 156-165. DOI: 10.26554/sti.2021.6.3.156-165.

[23] Stawiński, W., Węgrzyn, A., Mordarski, G., Skiba, M., Freitas, O., Figueiredo, S. (2018). Sustainable adsorbents formed from byproduct of acid activation of vermiculite and leached-vermiculite-LDH hybrids for removal of industrial dyes and metal cations. Applied Clay Science, 161, 6-14. DOI: 10.1016/j.clay.2018.04.007.

[24] Hu, H. (2020). NiFe-LDH nanosheet/carbon fiber nanocomposite with enhanced anionic dye adsorption performance. Applied Surface Science, 511, 145570 . DOI : 10.1016/j.apsusc.2020.145570.

[25] Xue, L., Gao, B., Wan, Y., Fang, J., Wang, S., Li, Y., Munoz-Carpena, R., Yang, R. (2016). High efficiency and selectivity of $\mathrm{MgFe}-\mathrm{LDH}$ modified wheat-straw biochar in the removal of nitrate from aqueous solutions. Journal Taiwan Institute of Chemical Engineers. 63, 312-317. DOI: 10.1016/j.jtice.2016.03.021.
[26] Palapa, N.R., Taher, T., Wijaya, A., Lesbani, A. (2021). Modification of $\mathrm{Cu} / \mathrm{Cr}$ Layered Double Hydroxide by Keggin Type Polyoxometalate as Adsorbent of Malachite Green from Aqueous Solution. Science \& Technology Indonesia, 6(3), 209-217. DOI: 10.26554/sti.2021.6.3.209-217.

[27] Palapa, N.R., Taher, T., Rahayu, B.R., Mohadi, R., Rachmat, A., Lesbani, A. (2020). $\mathrm{CuAl}$ LDH/Rice husk biochar composite for enhanced adsorptive removal of cationic dye from aqueous solution. Bulletin of Chemical Reaction Engineering \& Catalysis, 15(2), 525537. DOI: 10.9767/bcrec.15.2.7828.525-537.

[28] Vithanage, M., Ashiq, A., Ramanayaka, S., Bhatnagar, A. (2020). Implications of layered double hydroxides assembled biochar composite in adsorptive removal of contaminants: Current status and future perspectives. Science of the Total Environmental, 737(2020), 139718. DOI: 10.1016/j.scitotenv.2020.139718.

[29] Eskandari, S., Mohammadi, A., Sandberg, M., Eckstein, R.L., Hedberg, K., Granström, K. (2019). Hydrochar-amended substrates for production of containerized pine tree seedlings under different fertilization regimes. Agronomy, 9(7), 350. DOI: 10.3390/agronomy9070350.

[30] Akarsu, K., Duman, G., Yilmazer, A., Keskin, T., Azbar, N., Yanik, J. (2019). Sustainable valorization of food wastes into solid fuel by hydrothermal carbonization. Bioresoure Technology, 292, 121959. DOI: 10.1016/j.biortech.2019.121959.

[31] Zhang, T., Zhao, B., Chen, Q., Peng, X., Yang, D., Qiu, F. (2019). Layered double hydroxide functionalized biomass carbon fiber for highly efficient and recyclable fluoride adsorption. Applied Biological Chemistry, 62(1), 1-7. DOI: 10.1186/s13765-019-0410-z.

[32] Szabados, M., Adam, A.A., Traj, P., Murath, S., Baan, K., Belteky, P., Konya, Z., Kukovecz, A., Sipos, P., Palinko, A. (2020). Mechanochemical and wet chemical syntheses of CaIn-layered double hydroxide and its performance in a transesterification reaction compared to those of other Ca2M(III) hydrocalumites (M: Al, Sc, V, Cr, Fe, Ga) and $\mathrm{Mg}(\mathrm{II})-, \quad \mathrm{Ni}(\mathrm{II})-, \quad \mathrm{Co}(\mathrm{II})-\quad$ or $\mathrm{Zn}(\mathrm{II})$-based hydrotalcites. Journal of Catalysis, 391, 282297. DOI: 10.1016/j.jcat.2020.07.038.

[33] Gu, Z., Huang, Y., Wang, Y., Yuan, N., Ding, J. (2019). An aluminum silicate modified Ni$\mathrm{Al} \mathrm{LDHs}$ film to improve the corrosion resistance of AZ31 $\mathrm{Mg}$ alloy. Materials Letters, 252, 304-307. DOI : 10.1016/j.matlet.2019.06.010. 
[34] Chen, X., Lin, Q., He, R., Zhao, X., Li, G. (2017). Hydrochar production from watermelon peel by hydrothermal carbonization. Bioresoure Technology, 241, 236-243. DOI: 10.1016/j.biortech.2017.04.012.

[35] Normah, N., Palapa, N.R., Taher, T., Mohadi, R., Arsyad, F.S., Priambodo, A., Lesbani, A. (2021). Competitive Removal of Cationic Dye Using NiAl-LDH Modified with Hydrochar. Ecological Engineering \& Enviromental Technology, 22(4), 124-135. DOI: $10.12912 / 27197050 / 138120$.

[36] Firdaus, M.L., Krisnanto, N., Alwi, W., Muhammad, R., Allan, M. (2017). Adsorption of Textile Dye by Activated Carbon Made from Rice Straw and Palm Oil Midrib. Aceh International Journal of Science and Technology, 6(1), 1-7. DOI: 10.13170/aijst.6.1.5502.

[37] Sepehr, M.N., Al-Musawi, T.J., Ghahramani, E., Kazemian, H., Zarrabi, M. (2017). Adsorption Performance of Magnesium/Aluminum Layered Double Hydroxide Nanoparticles for Metronidazole From Aqueous Solution. Arabian Journal Chemistry, 10(5), 611-623. DOI: 10.1016/j.arabjc.2016.07.003.

[38] Pan, X., Zhang, M., Liu, H., Ouyang, S., Ding, N., Zhang, P. (2020). Adsorption behavior and mechanism of acid orange 7 and methylene blue on self-assembled three-dimensional $\mathrm{MgAl}$ layered double hydroxide: Experimental and DFT investigation. Applied Surface Science, 522, 146370. DOI: 10.1016/j.apsusc.2020.146370.

[39] Rathee, G., Awasthi, A., Sood, D., Tomar, R., Tomar, V., Chandra, R. (2019). A new biocompatible ternary Layered Double Hydroxide Adsorbent for ultrafast removal of anionic organic dyes. Scientific Reports, 9(1), 16225. DOI: 10.1038/s41598-019-52849-4.

[40] Shi, Z., Wang, Y., Sun, S., Zhang, C., Wang, H. (2020). Removal of methylene blue from aqueous solution using $\mathrm{Mg}-\mathrm{Fe}, \mathrm{Zn}-\mathrm{Fe}, \mathrm{Mn}-\mathrm{Fe}$ layered double hydroxide. Water Science and Technology, 81(12), 2522-2532. DOI: 10.2166/wst.2020.313.

[41] Pathania, D., Sharma, S., Singh, P. (2013). Removal of methylene blue by adsorption onto activated carbon developed from Ficus carica bast. Arabian Journal Chemistry, 10, S1445S1451. DOI: 10.1016/j.arabjc.2013.04.021.

[42] Idan, I.J., Abdullah, L.C., Choong, T.S.Y., Jamil, S.N.A.B.M. (2018). Equilibrium, kinetics and thermodynamic adsorption studies of acid dyes on adsorbent developed from kenaf core fiber. Adsorption Science \& Technology, 36(1-2), 694-712. DOI: $10.1177 / 0263617417715532$.
[43] Jivrakh, K.B., Kaki, S.B., Sharma, R., Mendu, S.S., Emadabathuni, A.K. (2020). Comparison of ammonia sorption properties and thermodynamic performance of adsorption-based thermal energy storage system for $\mathrm{MnCl}_{2}, \mathrm{CaCl}_{2}$, and their composites. Energy Storage, 2(4), e138. DOI: 10.1002/est2.138.

[44] Juleanti, N., Palapa, N.R., Taher, T., Hidayati, N., Putri, B.I., Lesbani, A. (2021). The Capability of Biochar-Based $\mathrm{CaAl}$ and $\mathrm{MgAl}$ Composite Materials as Adsorbent for Removal Cr (VI) in Aqueous Solution. Science \& Technology Indonesia, 6(3), 156-165. DOI: 10.26554/sti.2021.6.3.196-203.

[45] Raghav, S., Kumar, D. (2018). Adsorption Equilibrium, Kinetics, and Thermodynamic Studies of Fluoride Adsorbed by Tetrametallic Oxide Adsorbent. Journal Chemical \&. Engineering Data, 63(5), 16821697. DOI: 10.1021/acs.jced.8b00024.

[46] Chung, H.K., Kim, W.H., Park, J., Cho, J., Jeong, T.Y., Park, P.K. (2015). Application of Langmuir and Freundlich isotherms to predict adsorbate removal efficiency or required amount of adsorbent. Journal of Industrial and Engineering Chemistry, 28, 241-246. DOI: 10.1016/j.jiec.2015.02.021.

[47] Noreen, S., Khalid, U., Ibrahim, M., Javed, T., Ghani, A., Naz, S., Iqbal, M. (2020). ZnO, $\mathrm{MgO}$ and $\mathrm{FeO}$ adsorption efficiencies for direct sky Blue dye: Equilibrium, kinetics and thermodynamics studies. Journal Material. Research Technology, 9(3), 5881-5893. DOI: 10.1016/j.jmrt.2020.03.115.

[48] Batool, F., Akbar, J., Iqbal, S., Noreen, S., Bukhari, S.N.A. (2018). Study of Isothermal, Kinetic, and Thermodynamic Parameters for Adsorption of Cadmium: An Overview of Linear and Nonlinear Approach and Error Analysis. Bioinorganic Chemistry and Applications, 2018, 3463724. DOI: $10.1155 / 2018 / 3463724$.

[49] Lakhlifi, A., Dahoo, P.R., Picaud, S., Mousis, O. (2015). A simple van't Hoff law for calculating Langmuir constants in clathrate hydrates. Chemical Physics, 448, 53-60. DOI: 10.1016/j.chemphys.2015.01.004.

[50] Ali, I., Asim, M., Khan, T.A. (2012). Low cost adsorbents for the removal of organic pollutants from wastewater. Journal of Environmental Management, 113, 170-183. DOI: 10.1016/j.jenvman.2012.08.028.

[51] Chang, Y., Lai, J., Lee, D. (2016). Thermodynamic parameters for adsorption equilibrium of heavy metals and dyes from wastewaters: research updated. Bioresource Technology, 6(16), 31392-31399. DOI: 10.1016/j.biortech.2016.09.125. 